\title{
Magyar Nemzeti Bank: A koronavírus-járvány következtében új meccs kezdődött a világban - Cél a V alakú kilábalás*

\author{
HAJNAL MIHÁLY
}

Hazánkban 2018-at követöen a 2019-es gazdasági növekedés is közel 5 százalékos értéket mutatott. Ezzel Magyarország az európai országok növekedési rangsorának élmezőnyében szerepelt, és folytatódott a reálgazdasági felzárkózás az euróövezethez. 2020 első hónapjának adatai alapján minden esély megvolt rá, hogy a dinamikus növekedés az idei évben is tovább folytatódjon, azonban a gyorsan globálissá vált koronavirus-járvány alapjaiban új helyzetet teremtett a világgazdaságban.

A vírus legyengült állapotban érte el a világgazdaságot, miközben az elmúlt fél évszázad globalizációjának legérzékenyebb pontjait támadta meg. A rendkivüli környezetben a gazdaságpolitika számára nem lehet más cél, mint az egészségügyi védekezés támogatása, a gazdaság védelmével a hosszú távú hatások elkerülése, és az újraindulást megfelelöen elökészitve egy $V$ alakú kilábalás előkészitése. A kilábalás szempontjából három tényezö sorsdöntö: az induló fundamentális helyzet, a megfelelö gazdaságpolitikai mozgástér, illetve a válságkezelés minösége. Magyarországon minden adott a V alak eléréséhez.

Várakozásaink alapján a makrogazdasági adatokat az idei évben várhatóan jelentös változékonyság és kettösség fogja jellemezni. 2020 elsö felében a koronavírus-járvány negatív gazdasági hatásai miatt a növekedés érdemben lassul, a második negyedévben a GDP csökkenhet, majd az év második felétöl a negatív hatások kifutásával és a korábban kiesö gazdasági aktivitás helyreállitásával a hazai növekedés, a munkaeröpiac, a hitelezés és a külkereskedelem is újra élénkül.

Az év első hónapjaiban a hazai fogyasztóiár-index a régió több országához hasonlóan néhány, a világpiaci folyamatoknak erösen kitett, változékony áralakulású tétel következtében átmenetileg a jegybanki toleranciasáv fölé emelkedett. A világpiaci nyersanyagárak - föként a köolajé - számottevö csökkenése következtében

* Az elemzés az MNB 2020. márciusi Inflációs jelentése alapján készült.

https://doi.org/10.47630/KULG.2020.64.3-4.25

Hajnal Mihály, a Magyar Nemzeti Bank vezető közgazdasági elemzője. E-mail: hajnalm@mnb.hu 
az infláció várakozásaink alapján rövid távon a toleranciasávban alakul, és gyors ütemben a 3 százalékos jegybanki cél alá csökken.

\section{Ahonnan indulunk - 2019, egy újabb sikeres év}

A hazai gazdasági kibocsátás 2019 egészében 4,9 százalékkal bővült, ezzel az európai növekedési rangsor élmezőnyébe tartozott, csupán az ír GDP növekedése előzte meg. Mindezek hatására folytatódott a 2013 óta megfigyelhető reálgazdasági felzárkózás az európai gazdaságokhoz. Ráadásul tavaly és az elmúlt két év átlagában a felzárkózás üteme meghaladta a megcélzott 2-3 százalékos növekedési többletet: 2019-ben ez az érték 3,7 százalékpont, míg két év átlagában 3,3 százalékpont volt. A gazdasági növekedést felhasználási oldalon elsősorban a beruházások és a fogyasztás, termelési oldalon a piaci szolgáltatások, valamint az építőipari és ipari ágazatok támogatták. A belső keresleti tételek növekedésével összhangban az áruimport bővülési üteme meghaladta a kivitel növekedését. A negatív áruegyenleget a változatlanul pozitív szolgáltatásegyenleg nagy részben ellensúlyozta.

A belső felhasználási tételek változatlanul jelentősen hozzájárultak a növekedéshez. A finanszírozási folyamatok 2019-ben is kedvezően alakultak, és a pozitív növekedési impulzusok közel kétharmada a hitelpiac felöl érkezett. A vállalati és a kkv-hitelek két számjegyü bővülése a magas kapacitáskihasználtsággal és az alacsony kamatkörnyezettel párhuzamosan nagymértékben hozzájárult a vállalati beruházások és a GDP emelkedéséhez, aminek hatását a 2019 júliusától elérhető Növekedési Kötvényprogram fokozta, további 450 milliárd forintos keretösszegben biztosítva forrást a cégek számára. Mindezek hatására a hazai beruházási ráta 2019ben 28,6 százalékon alakult, ezzel európai összevetésben az élmezőnybe tartozik.

A magyar gazdaság a munkaerőpiaci fordulat következtében az elmúlt években megközelítette a teljes foglalkoztatás állapotát, a nemzetgazdasági foglalkoztatottak száma meghaladta a 4,5 millió föt (ez historikus csúcs). 2019-ben folytatódott a nemzetgazdasági bruttó átlagkeresetek két számjegyű növekedése, amit a bérezési alapfolyamatot meghatározó, historikusan feszes munkaeröpiaci környezet mellett a minimálbér és a garantált bérminimum emelése, valamint a szociális hozzájárulási adó csökkentése is magyaráz. Az ötszázalékos bővülést mutató lakossági fogyasztást a háztartások magasabb rendelkezésre álló jövedelme mellett a júliusban elindított babaváró támogatáshoz kapcsolódó hitelfelvétel is elősegítette. A program keretében decemberrel bezárólag közel 500 milliárd forint értékben kötöttek szerződéseket a 
Magyar Nemzeti Bank: A koronavírus-járvány következtében új meccs...

fiatal házaspárok. Ezzel párhuzamosan a háztartások beruházási aktivitása is dinamikus növekedést mutatott, 2019 egészében 21 ezer újonnan épült lakást adtak át.

Az elmúlt időszakban a volatilis, a világpiaci nyersanyagárak mozgására érzékeny tételek (üzemanyag, élelmiszer) a hazai infláció szokásosnál nagyobb változékonyságát okozták. A feldolgozatlan élelmiszerek árainak változékonyságában az év második felében szerepet játszott az afrikai sertéspestis következtében megemelkedő sertéshús, valamint a szezonális élelmiszerek árdinamikája. Az üzemanyagárak a világpiaci olajárak változékonyságát lekövetve alakultak az év során. Összességében az infláció az év elején a toleranciasáv 2015-ös bevezetését követően először emelkedett a sáv fölé, és februárban 4,4 százalékon alakult, míg a tavalyi év egészét tekintve 3,4 százalékos értéket mutatott. Az inflációs tendenciákat megragadó, adószürt maginfláció az élénk bérezéssel és a belső kereslettel összhangban februárra 3,8 százalékra emelkedett. A mutatónak az év második felében bekövetkezett emelkedését elsősorban a feldolgozott hús- és tejtermékek árváltozása miatt növő feldolgozott élelmiszerek ára hajtotta.

\section{A koronavírus-járvány minden korábbi forgatókönyvet teljesen átírt}

A globális növekedés 2019-ben 2,9 százalékon alakult, mely a 2008-2009-es globális gazdasági válság óta a legalacsonyabb érték. Így a 2020 elején megjelent koronavírus-járvány a világgazdaságot legyengült állapotban érte. A fertőzés következtében a gazdasági kilátások a korábbiaknál nagyságrendileg bizonytalanabbakká váltak, a feltételek napról napra változnak. A járvány hatására kialakult bizalmi hiány az elmúlt hetek során pénzügyi és gazdasági krízissé terebélyesedett, amely számos csatornán keresztül befolyásolja a gazdasági ökoszisztémát. Keresleti oldalról a számottevően visszaeső turizmus, a tartós fogyasztási cikkek vásárlásának és a beruházásoknak az elhalasztása; kínálati oldalról az ellátási láncok szakadása; míg a gazdaságpszichológiai oldalról a kockázatvállalási hajlandóság csökkenése lehet a meghatározó. A járvány hatásai ráadásul érdemben nagyobbak lehetnek a korábbi hasonló esetekhez képest (pl.: SARS), hiszen a világgazdaság jóval integráltabbá vált az idők során. A krízis hatásai jelenleg még makrogazdasági adatokon nehezen számszerüsíthetők, viszont az előretekintő bizalmi indexek már historikus mélypontjukra estek, az új munkanélkülisegély-kérelmet benyújtók száma az Egyesült Államokban soha nem látott magasságokba szökött, valamint a VIX index is érdemben emelkedett. 
A válságok és az azokból való kilábalás jellemzőik alapján különböző alakot ölthetnek. A szakirodalom megkülönbözteti a V, W, L, U alakú válságokat. A helyreállás minősége és gyorsasága alapvetően három kulcstényezőtől függ megitélésünk alapján. Egyrészről fontos, hogy a válság az adott gazdaságot milyen fundamentális helyzetben éri. Emellett elengedhetetlen a megfelelő gazdaságpolitikai mozgástér. Végezetül pedig a válságkezelés minősége is kulcstényező a helyreállás sebességét illetően.

A fent említett három kulcstényezőt külön-külön megvizsgálva leszürhető, hogy hazánk induló pozíciója biztató. Hazánk az elmúlt száz évben nem vágott még bele egy globális válsághelyzet kezelésébe a jelenlegihez hasonló, erős fundamentumokkal. Az egyensúlyi mutatók stabilak, a nettó külső adósság eltűnőben van, nincs lakossági devizahitel-állomány, csökkenő pályán az államadósság, ráadásul a költségvetés hiánya folyamatosan alacsony volt az utóbbi nyolc évben. Mindezek hatására a gazdaságpolitika mozgástere is igen jelentős, megfelelő beavatkozási potenciállal bír. Mindehhez hozzájárul az is, hogy a Magyar Nemzeti Bank, szemben más jegybankok gyakorlatával, az elmúlt években szükítette jegybankmérlegét, így e tekintetben is érdemi mozgástér áll rendelkezésre. Összességében tehát elmondható, hogy jelenleg minden okunk megvan abban bízni, hogy a járvány lecsengésével (majdnem) ott folytatjuk, ahol abbahagytuk, és jó eséllyel egy V alakú lefutással kerülünk ki a válságból.

A globális járványhelyzet gazdasági következményeit illetően a legfontosabb kérdés, hogy milyen súlyosan és milyen hosszan áll fenn az egészségügyi veszélyhelyzet. A márciusi Inflációs jelentés alappályájában azzal a feltevéssel éltünk, hogy a koronavírus enyhe és átmeneti hatásokkal bír a hazai és a világgazdaság növekedésére nézve, persze a kilábalás sebessége még így is régiónként eltérő lehet. A 2020-as év növekedési szempontból kétarcú lehet. Míg az első fél évben - föként a második negyedévben - a karantén és a gyárleállások következtében érdemi visszaesés valószínűsíthető, addig 2020 végén a gazdaság újraindulására és a korábban elhalasztott aktivitás visszapótlására számítunk. Természetesen a jelenleg rohamosan változó környezet nagyfokú bizonytalanságokat hordoz a makrogazdasági adatokra nézve, a prognózisokat is napról napra befolyásolva. A gazdaságpolitika feladata jelenleg kettős: elsőként az egészségügyi védekezéshez szükséges források biztosítása, a károk enyhítése és a gazdaságok stabilizálása. Ezt követi második vonalként a növekedési potenciál szempontjából fontos képzett munkaerő és a hatékony vállalati kapacitások megőrzése, továbbá a felkészülés a gazdaság zökkenőmentes újraindítására. 
Magyar Nemzeti Bank: A koronavírus-járvány következtében új meccs...

A kialakult helyzet hatásaiban leginkább egy természeti katasztrófához hasonlítható, ahol számszerủ prognózist készíteni szinte lehetetlen. Emiatt átmenetileg szakítottunk azzal a gyakorlattal, hogy egy kitüntetett alappálya köré építjük a prognózisunkat. Jelenlegi elörejelzésünk minden változó esetében egy tartományt ad meg, amit két egymással egyenrangú pálya alapján határoztunk meg. Hangsúlyozzuk, hogy az alappályáink mögötti információs bázis a március eleji, a vírus magyarországi megjelenésének időpontja körüli állapotot tükrözi. Ezek a kilátások a magyar gazdaság 2-3 százalék közötti növekedését vetítik előre, azonban a gazdaság újraindulása 2021-ben a bázishatások következtében is érdemi visszapattanást fog hozni.

A járvány terjedése a makrogazdasági környezetben általában megszokott lineáris hatások helyett erős nem lineáris hatásokkal jelentkezik, ami az ágazatok széles körében szinte azonnal teljes leállásokat is okozhat. Elörejelzésünk elkészítése során úgy számoltunk, hogy a koronavírus hatásainak leginkább kitett ágazatok egyhavi leállása jelentősen visszafoghatja a gazdasági növekedést. A jármügyártás, a turizmus, a kulturális szolgáltatások, valamint a szállítmányozási szektor várt visszaesése összességében 0,9-1,3 százalékponttal mérsékelheti a hazai GDP-t. Elöretekintve arra számítunk, hogy egy idén bekövetkező számottevőbb visszaesés erősebb felpattanást okozhat a jövő évi gazdasági növekedésben. A háztartások fogyasztása továbbra is a gazdasági növekedés legfontosabb tényezője marad, bár bővülésének üteme mérséklődik a korábbi időszakokban látott értékekhez képest. A fokozódó bizonytalanság hatására az óvatossági motívum szerepe a szektor viselkedésében erősödik, így a lakossági megtakarítások várhatóan emelkednek.

Az üzemanyagárak számottevő csökkenése - kizárólag március hónapban 85 forinttal mérséklődtek a benzinárak - következtében az infláció várakozásaink alapján rövid távon a toleranciasávban alakul, majd gyors ütemben a 3 százalékos jegybanki cél alá csökken. A koronavírus okozta mérséklődő gazdasági aktivitás következtében általánosan visszafogottabb külső keresletre és inflációra számítunk, ami elsősorban az iparcikkek árazását fogja vissza. A gyengülő hazai konjunktúra és a lassuló bérdinamika a piaci szolgáltatások esetében is alacsonyabb árazási magatartást okozhat. Az előrejelzési horizonton a koronavírus negatív gazdasági következményeinek, illetve a romló külső konjunktúra hatásainak enyhülését követően a belső kereslet újbóli erősödésére, és bázishatások miatt az árdinamika átmeneti emelkedésére számítunk. Így előrejelzésünk szerint az infláció az elörejelzési horizont végén a 3 százalékos inflációs célon stabilizálódik. 